\title{
Is there an FSH-releasing factor?
}

\author{
Vasantha Padmanabhan ${ }^{1}$ and Alan S. McNeilly ${ }^{2}$ \\ ${ }^{1}$ Department of Pediatrics and the Reproductive Sciences Program, University of Michigan, \\ Ann Arbor, MI 48109, USA; and ${ }^{2}$ MRC Human Reproductive Sciences Unit, Edinburgh \\ EH3 9ET, UK
}

\begin{abstract}
A thorough understanding of the factors that regulate the secretion of FSH is critical for the development of efficient methods for fertility regulation. The purpose of this review is to evaluate what is currently known about the existence of FSH-releasing factor(s). It considers the obstacles encountered in understanding the control of FSH secretion, current knowledge of the nature of FSH secretion and the mechanisms involved in controlling FSH secretion, the arguments that have been posed against the need for an FSH-releasing factor and finally the evidence available to date supporting the existence of FSH-releasing factor(s).
\end{abstract}

Follicle-stimulating hormone $(\mathrm{FSH})$ is a key reproductive hormone involved in the regulation of follicular development. In comparison with luteinizing hormone (LH), progress in understanding the secretory nature of $\mathrm{FSH}$ and its control is limited. Part of the problem in assessing the secretory dynamics of FSH in the periphery has stemmed from its long half-life and molecular heterogeneity (for review, see Ulloa-Aguirre et al., 1995). The inability of existing assays to recognize all circulating isoforms of FSH may also have been a contributing factor. In addition, because gonadotrophin $\alpha$-subunit is secreted in a pulsatile manner (Hall et al., 1990), and FSH and LH share a common $\alpha$-subunit, it is unclear whether the episodic pattern of $\mathrm{FSH}$ release, when observed, is a reflection of gonadotrophin $\alpha$-subunit or LH crossreactivity. In spite of these caveats, several advances have been made in our understanding of the control of FSH secretion.

\section{Current understanding of the nature of FSH secretion}

\section{Basal and episodic modes of FSH release}

In contrast to the absolute dependence of the LH secretory system on GnRH (LHRH) pulsatility, FSH secretion appears to be regulated by a dual mechanism, one mechanism controlling a basal (constitutive) and the other a pulsatile (regulated) component. That a substantial portion of circulating $\mathrm{FSH}$ reflects constitutive secretion and is not reliant on immediate stimulus secretion coupling is supported by the following findings: (1) continued release of FSH for prolonged periods in hypothalamic disconnected sheep (Clarke et al., 1983); (2) continued release of FSH in hypophysectomized rats bearing pituitary transplants

Email: vasantha@umich.edu

Supported by NIH HD 34731 and NSF 9725943 under the kidney capsule (DePaolo, 1991); and (3) continued release of FSH by long-term pituitary cultures (Sheridan et al., 1979). This component of FSH release appears to be dependent on the availability of translatable FSH $\beta$ mRNA (Clarke et al., 1993; Muyan et al., 1994; Farnworth, 1995).

What is the evidence available in support of the existence of an episodic component of FSH secretion? Barring a few studies, in which distinct patterns of episodic FSH have been surmised from peripheral measurements (for example, in rats: Culler and Negro-Vilar, 1987), pulses of $\mathrm{FSH}$ measured at the periphery in general are not as discrete as pulses of LH (for example, in sheep: Wallace and McNeilly, 1986; and humans: Gross et al., 1987). In most studies, investigators resort to statistical approaches to deconvolute FSH pulses. This obscurity in defining FSH secretory patterns can be overcome by assessing secretory patterns of $\mathrm{FSH}$ at a site close to release in the hypophyseal portal vasculature.

Hypophyseal portal blood as a source to assess FSH secretory dynamics

Continuous withdrawal of hypophyseal portal blood, a method pioneered by Clarke et al. (1983), in addition to providing a direct and detailed understanding of the pulsatile secretion of GnRH in sheep, provides an excellent opportunity to determine secretory patterns of gonadotrophins near their sites of release (Midgley et al., 1997). During hypophyseal portal collection, portal vessels are lesioned at the surface of the pituitary. Gonadotrophins may enter the portal circulation via any of three routes: (1) from gonadotrophs located in the pars tuberalis surrounding the stalk of the adenohypophysis; (2) from retrograde flow through hypophyseal portal vessels; and (3) from drainage of sinusoids lesioned in the pituitary.

Comparison of LH patterns in simultaneous samples of peripheral and hypophyseal portal blood of ovariectomized ewes demonstrates the outstanding resolution that 
(a)
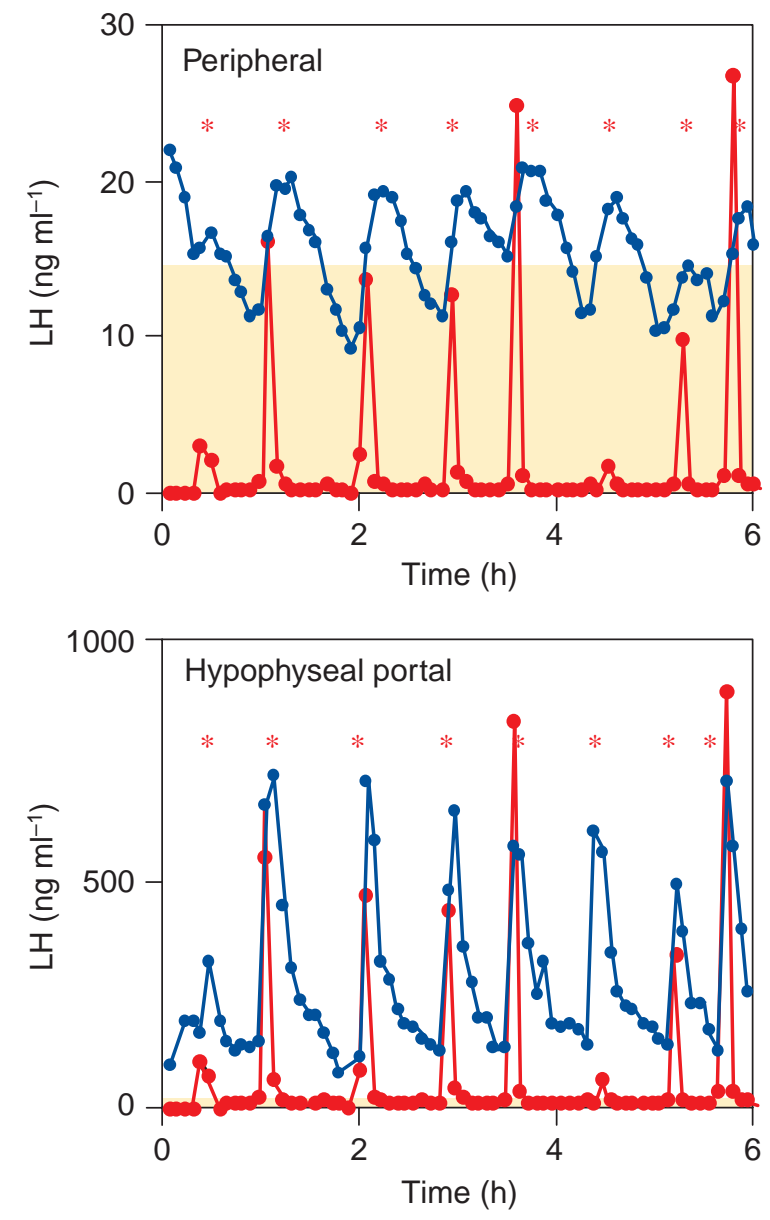

(b)
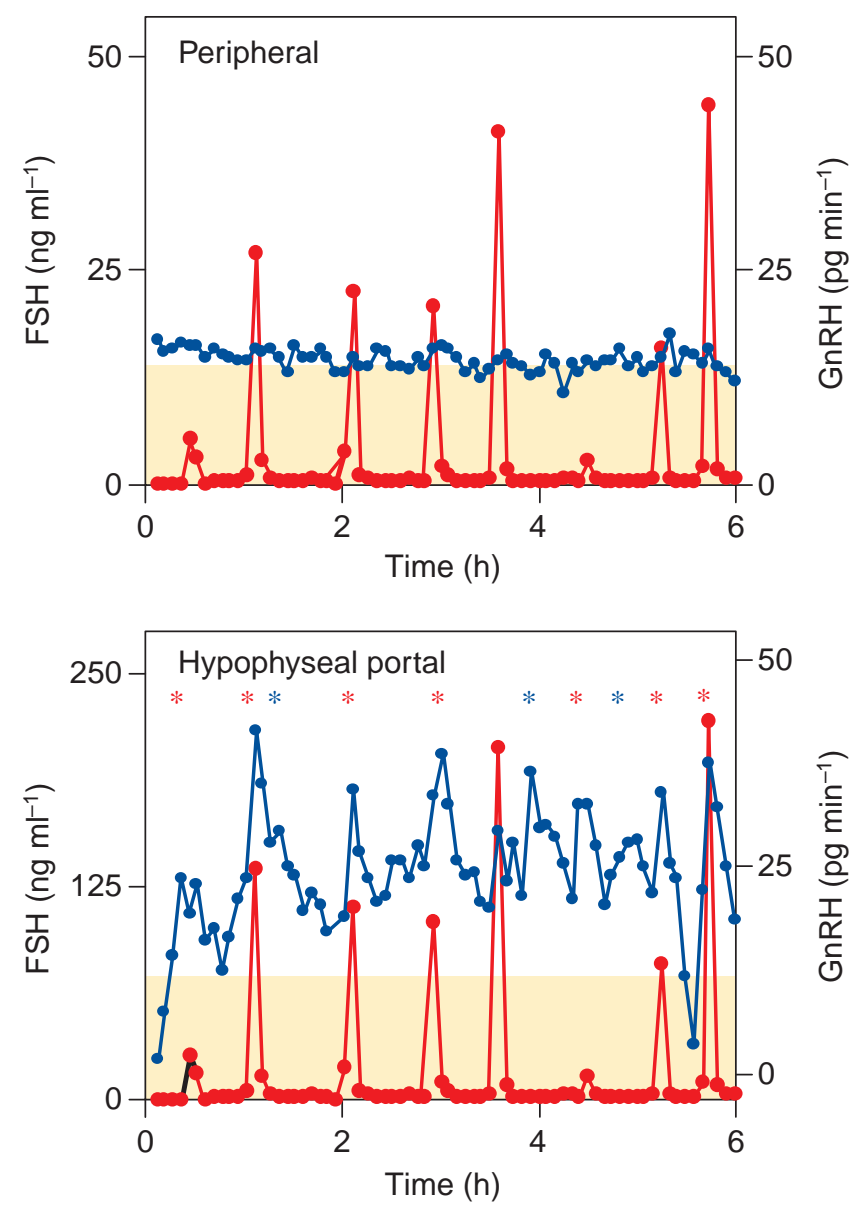

Fig. 1. Patterns of GnRH (red), hypophyseal portal and jugular (peripheral) LH (a) and FSH (b) (blue) from an ovariectomized ewe during anoestrus (V. Padmanabhan, G. D. Dahl, N. P. Evans, F. J. Karsch and J. Van Cleeff, unpublished). Red asterisks indicate GnRHassociated pulses and blue asterisks the non-GnRH-associated pulses. Note: (1) the discreteness and magnitude of LH in hypophyseal portal blood; (2) the one-to-one relationship of both hypophyseal portal and peripheral $\mathrm{LH}$ with $\mathrm{GnRH}$; (3) the dynamic pattern of FSH in hypophyseal portal but not peripheral secretion; and (4) the GnRH-associated and non-GnRH-associated pulses of FSH. Differences in the thresholds of LH and FSH in peripheral and hypophyseal portal circulation appear to reflect the recirculating concentrations of LH and FSH (yellow area) and is the sum of their secretion, clearance and peripheral metabolism.

is achieved in characterizing secretory patterns of pituitary hormones using this approach (Fig. 1a). Because blood is collected close to the site of release, and masking of the true secretory patterns by recirculating hormones is minimized by the massive secretory output, $\mathrm{LH}$ is concentrated several-fold in hypophyseal portal compared with peripheral blood, where its pattern of secretion is more discrete than in the peripheral circulation. Furthermore, LH pulse patterns in hypophyseal portal, as in peripheral, circulation follow GnRH patterns closely, with a virtual one-to-one relationship between the two hormones. The discrete $\mathrm{LH}$ pattern and its close relationship to $\mathrm{GnRH}$ indicate that the dynamics of pituitary hormones observed in pituitary portal blood reflect the secretory dynamics and not leakage from damaged pituitary cells.

Characterization of FSH patterns in hypophyseal portal blood reveals a dynamically changing pattern of FSH that is hard to surmise from peripheral measurements (Fig. 1b). In sheep, studies using the experimental approach described above and a well-characterized FSH assay that crossreacts minimally with alpha subunit $(<0.3 \%)$ have demonstrated unequivocally that there is an episodic component of FSH secretion (Padmanabhan et al., 1997). This finding corroborates what has been surmised previously on the basis of peripheral measurements of $\mathrm{FSH}$. What is the nature of this episodic FSH secretion, and can it be 


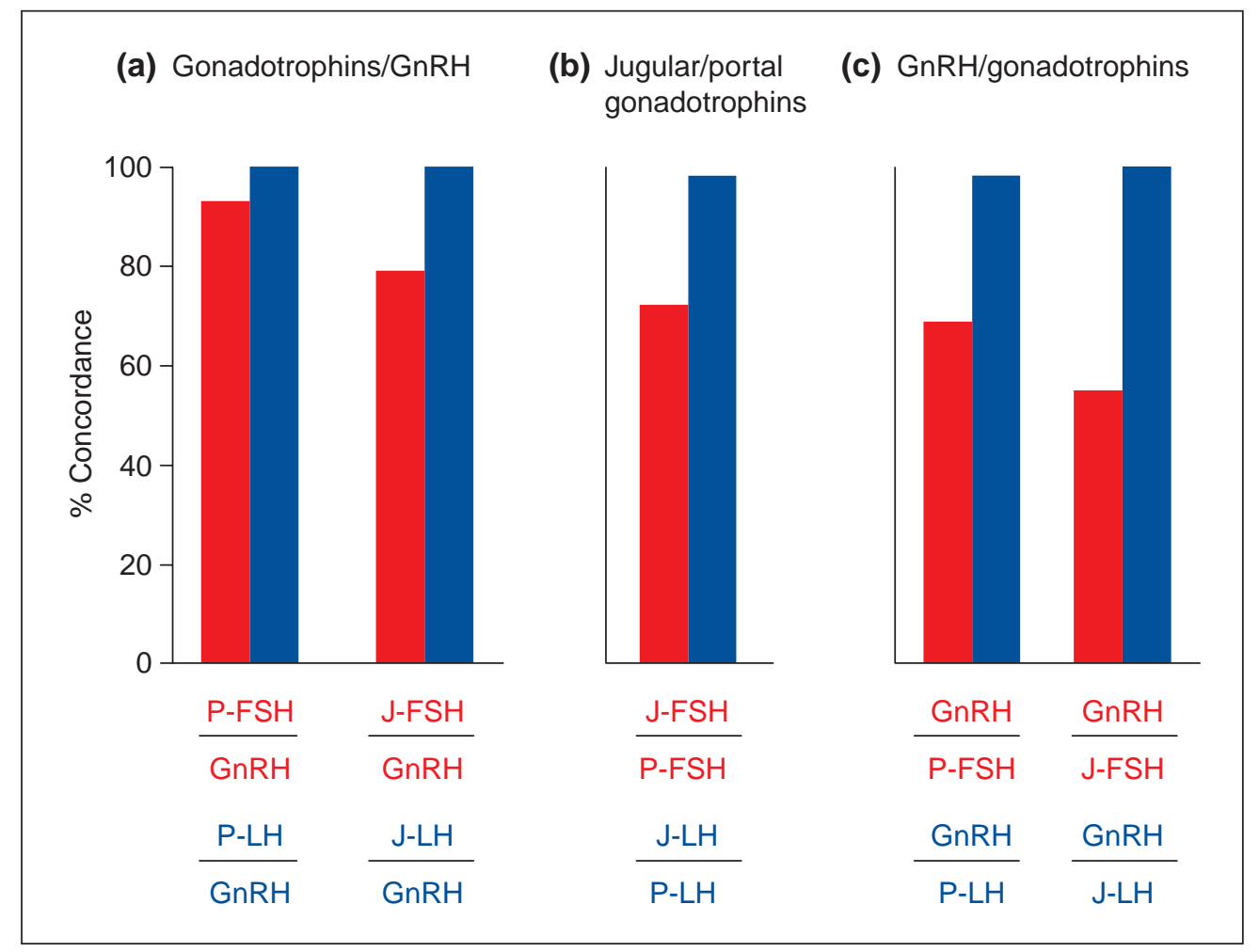

Fig. 2. Pulse concordance relationships of hypophyseal portal (secreted; P) and jugular (peripheral; J) FSH and GnRH in ovariectomized ewes (red; from Padmanabhan et al., 1997). Although pulses in peripheral circulation are not as discrete and visually identifiable as they are in hypophyseal portal circulation, peripheral pulses identified using pulse detection algorithms were used to assess these relationships. When the percentage of GnRH with corresponding FSH pulses was computed $(\mathrm{GnRH}$ as the denominator), the concordance estimate was $93 \%$ for portal FSH and $73 \%$ for peripheral FSH (a). The concordance between hypophyseal portal and peripheral FSH was $70 \%$ (b). In contrast, when the percentage of FSH pulses showing an association with $\mathrm{GnRH}$ (FSH as the denominator) was computed (note there are more pulses of FSH than of $\mathrm{GnRH}$ ), only $68 \%$ of FSH pulses were found to be associated with GnRH owing to the existence of non-GnRH-associated pulses of FSH (32\%) (c). For comparison, the corresponding relations of $\mathrm{LH}$ are provided (blue). Irrespective of whether GnRH or LH was used as the denominator, there is a $100 \%$ concordance between $\mathrm{GnRH}$, hypophyseal portal $\mathrm{LH}$, and peripheral $\mathrm{LH}$, demonstrating that $\mathrm{GnRH}$ is the sole regulator of $\mathrm{LH}$ pulsatility. (Redrawn from Padmanabhan et al., 1997.)

accounted for completely by the changes in $\mathrm{GnRH}$ secretion?

\section{Evidence for the existence of GnRH-independent FSH pulses}

Key to our understanding of whether GnRH can account for the pulsatile control of FSH secretion is the determination of whether all identified pulses of $\mathrm{FSH}$ are concurrent with $\mathrm{GnRH}$ pulses. Cursory assessment of the data shown (Fig. 1) reveals the existence of both GnRH-associated (red asterisks) and non-GnRH-associated (blue asterisks) pulses of FSH in hypophyseal portal blood. The up slope of some of the GnRH-associated FSH pulses in some instances precedes the start of $\mathrm{GnRH}$ pulses. This finding contrasts with the pattern of $\mathrm{LH}$ in which increases in $\mathrm{LH}$ are coincident with, or follow, GnRH increases. As the blood passing from the hypophyseal portal circulation is not returned (washout can lead to fast disappearance times), increases in FSH concentrations provide evidence for incremental, active secretion. Does this mean that there is a second component even in the $\mathrm{GnRH}$-associated pulses? Studies in ovariectomized sheep have established that almost all (93\%) of the GnRH pulses show correspondence with FSH pulses (Padmanabhan et al., 1997) (Fig. 2). These GnRH-associated pulses accounted for only twothirds of the total FSH pulses observed. Thus, one-third of the total FSH pulses remained unaccounted for by $\mathrm{GnRH}$.

Further evidence for a GnRH-independent, pulsatile FSH component comes from the studies of Culler and NegroVilar (1987) demonstrating that combined administration of $\mathrm{GnRH}$ antiserum and a $\mathrm{GnRH}$ antagonist to castrated male rats abolishes LH pulsatility completely without abolishing FSH pulsatility. Pau et al. (1991) corroborated 


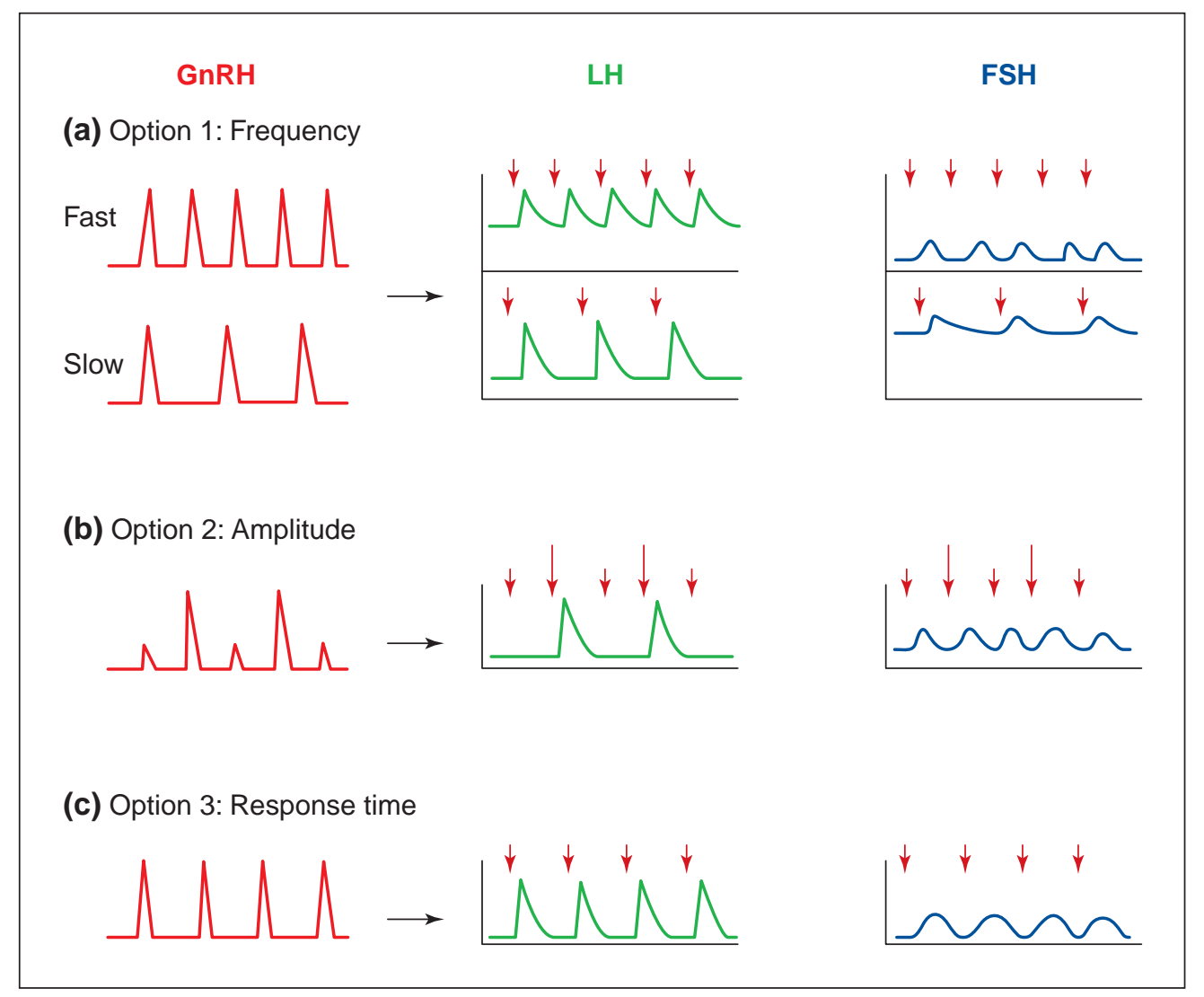

Fig. 3. Schematic representation of the three proposed mechanisms by which a single-releasing hormone $(\mathrm{GnRH})$ can differentially regulate FSH secretion. Option 1 (a): changes in GnRH frequency, with high frequency GnRH pulses favouring the overall concentration of $\mathrm{LH}$ over FSH and low frequency GnRH favouring FSH over LH. Option 2 (b): amplitude modulation, with low amplitude GnRH selectively releasing FSH over LH. Option 3 (c): changes in response time, with FSH taking longer to respond than LH. Options 1 and 3 do not reasonably explain the occurrence of additional non-GnRH-associated pulses of FSH. In addition, since LH is more sensitive than FSH to GnRH (Normolle et al., 1997), option 2 does not explain the occurrence of non-GnRH-associated pulses of FSH.

these findings in rabbits by administering phentolamine (an $\alpha$-adrenergic antagonist) intravenously to disrupt the generation of medial basal hypothalamic GnRH pulses, or $\mathrm{GnRH}$ antiserum intra-hypothalamically to immunoneutralize endogenous GnRH pulses. Both treatments selectively suppressed LH pulsatility but not FSH pulsatility. What other lines of evidence support the presence of additional control mechanisms for $\mathrm{FSH}$ ?

\section{Differential regulation of $\mathrm{LH}$ and $\mathrm{FSH}$}

Although $\mathrm{GnRH}$ has been proven unquestionably to induce the release of both $\mathrm{LH}$ and FSH (Schally et al., 1971), the patterns of $\mathrm{LH}$ and FSH have been shown to diverge often. For instance, disruption of $\alpha$-adrenergic neurotransmission results in a rapid decrease in $\mathrm{LH}$ but not FSH pulse frequency (Dobson and Ward, 1977; Chappel et al., 1984). Catecholamine turnover within specific hypothalamic nuclei accompanies alterations in LH but not FSH secretion (Barraclough and Wise, 1982). Dissimilarities in the responses of $\mathrm{LH}$ and $\mathrm{FSH}$ to electrochemical stimulation (Chappel and Barraclough, 1976), lesion (Bishop et al., 1972), gonadal steroids (Kalra, 1976; Strobl and Levine, 1988; Gharib et al., 1990), gonadal proteins (Gharib et al., 1990; Baird et al., 1991) and GnRH antagonists (Kartun and Schwartz, 1987; Hall et al., 1990; Normolle et al., 1997) have also been observed. Both LH and FSH are often produced in the same gonadotrophs and may even be stored in the same secretory granules within gonadotrophs (Childs, 1986). If GnRH is the only hypothalamic regulator of FSH, what mechanisms might explain the discordance in the episodic pattern of LH and FSH secretion?

\section{Mechanisms proposed to explain why differential release of $\mathrm{LH}$ and $\mathrm{FSH}$ does not require the presence of an $\mathrm{FSH}-$ releasing factor}

\section{GnRH input pattern}

Several mechanisms have been proposed to explain the 
apparent paradox of differential LH and FSH release (Fig. 3). First, an alteration in $\mathrm{GnRH}$ pulse frequency has been recognized as a mechanism by which a single releasing hormone can regulate $\mathrm{LH}$ and FSH differentially, slower frequencies favouring $\mathrm{FSH}$ release and faster frequencies favouring $\mathrm{LH}$ release (Wildt et al., 1981; Clarke et al., 1984, Marshall et al., 1992) (Fig. 3a). Although the overall threshold of FSH secretion can certainly be mediated by changes in GnRH pulse frequency, this mechanism does not help explain the existence of the non-GnRH-associated pulses of FSH discussed above.

Second, differential sensitivity of the subpopulation of gonadotrophs that secrete LH and FSH (Denef et al., 1978; Childs 1985) or threshold differences in the response to $\mathrm{GnRH}$ (amplitude modulation) with small GnRH infusions favouring FSH secretion (Wise et al., 1979; Wu et al., 1987) have been suggested as alternative means by which $\mathrm{LH}$ and FSH can be regulated differentially (Fig. 3b). Dose-response studies in vitro (Normolle et al., 1997) show $\mathrm{LH}$ and not FSH to be more sensitive to GnRH. Studies comparing the secretory responses of FSH and $\mathrm{LH}$ to different doses of $\mathrm{GnRH}$ are lacking in vivo.

Third, different response times of $\mathrm{LH}$ and FSH to GnRH (Schwartz et al., 1985) may be a means by which non$\mathrm{GnRH}$-associated pulses can originate (Fig. 3c). However, this mechanism does not explain the disproportionately larger number of FSH pulses (compared with $\mathrm{GnRH}-\mathrm{LH}$ pulses) that are often encountered. Furthermore, exogenous administration of pulsatile $\mathrm{GnRH}$, at least in studies in vitro, leads to synchronous and accountable increases in LH and FSH (Weiss et al., 1990).

If any of the above three arguments are a valid explanation for the non-GnRH-associated pulses of FSH, FSH pulsatility should be abolished after the blockade of $\mathrm{GnRH}$ action. However, FSH pulsatility is not abolished since episodic FSH secretion has been shown to persist even after elimination of endogenous GnRH activity (Culler and Negro-Vilar, 1987; Kartun and Schwartz, 1987; Hall et al., 1990). These findings provide the strongest evidence in support of the existence of an additional non-GnRHdependent mechanism regulating FSH pulsatility.

\section{Metabolic clearance versus endocrine milieu}

Differences in metabolic clearance rates may explain the apparent differences in $\mathrm{LH}$ and $\mathrm{FSH}$ release. Such differences are well documented (for review, see Ulloa-Aguirre et al., 1995) and certainly contribute to changes in baseline concentrations of circulating $\mathrm{LH}$ and $\mathrm{FSH}$. Although pulses of $\mathrm{FSH}$ can be obscured by slow clearance, differences in the clearance rates of $\mathrm{LH}$ and $\mathrm{FSH}$ cannot explain the asynchronous initiation of FSH pulses (Culler and Negro-Vilar, 1987; Pau et al., 1991; Padmanabhan et al., 1997).

Differences in the circulating endocrine milieu (gonadal steroids and peptides) may also have differential effects on the release patterns of $\mathrm{LH}$ and FSH (Savoy-Moore and Schwartz, 1980; McNeilly 1988; Baird et al., 1991).
Oestradiol is a major negative feedback regulator of both $\mathrm{LH}$ and FSH secretion. Differential effects of oestradiol on $\mathrm{LH}$ and $\mathrm{FSH}$ appear to be mediated both via alteration of hypothalamic GnRH secretion (Marshall et al., 1992; Karsch and Evans, 1996) and via direct effects at the pituitary. Direct effects of oestradiol appear to be mediated mainly at transcription and translation (for review, see Gharib et al., 1990; Brown and McNeilly, 1999). Oestradiol has also been shown to cause the movement of granules containing $\mathrm{LH}$ to the plasma membrane in ovine gonadotrophs without altering the distribution of granules containing FSH (Thomas and Clarke, 1997). Evidence that gonadally derived inhibin is involved in selectively suppressing overall FSH production (McNeilly, 1988; Ying 1988; Baird et al., 1991) is also very strong. Although the effects of these long-range endocrine regulators in altering the baseline concentration of $\mathrm{FSH}$ is uncontested, they do not provide an explanation for the occurrence of discordant $\mathrm{LH}$ and $\mathrm{FSH}$ pulses in gonadectomized animals (Culler and Negro-Vilar, 1987; Pau et al., 1991; Padmanabhan et al., 1997).

None of the arguments posed thus far provide sufficient explanation for the asynchronous episodic $\mathrm{LH}$ and $\mathrm{FSH}$ release. Is the non-GnRH-associated episodic $\mathrm{FSH}$ release the consequence of a changing local pituitary environment having an impact on the constitutive secretagogueindependent mode of FSH secretion or is a separate neural trigger required to explain fully the differential control of $\mathrm{LH}$ and FSH secretion?

\section{Pituitary control}

An inherent pituitary-driven mechanism (Chappel, 1985) may explain the non-GnRH-associated episodic FSH release. This possibility has not been fully tested in vivo in $\mathrm{GnRH}$-deficient models using frequent sampling paradigms, but the absence of a pulsatile pattern of $\mathrm{FSH}$ release from pituitary tissue in vitro (Turgeon and Waring, 1982) is not consistent with this hypothesis. Another possibility is that the non-GnRH-associated releases of FSH are caused by changes in locally produced inhibin, activin or follistatin (Fig. 4). This hypothesis is supported by the fact that activins, inhibins and follistatins are produced in the anterior pituitary (DePaolo et al., 1991; Mather et al., 1992).

FSH biosynthesis and release are inhibited by inhibins and follistatins and stimulated by activins (for review, see Ying, 1988; DePaolo et al., 1991; Mather et al., 1992). Activin is more potent than $\mathrm{GnRH}$ at regulating $\mathrm{FSH} \beta$ mRNA (Weiss et al., 1992) and the effects of GnRH appear to be mediated via alterations in local activin availability (Besecke et al., 1996). Activins, inhibins and follistatins were thought originally to be produced only at the gonads and to act in an endocrine manner to modulate FSH secretion. Although the evidence supporting an endocrine role for inhibin is strong (Baird et al., 1991), some studies have questioned an endocrine role for follistatin and activin (Muttukrishna et al., 1996; McConnel et al., 1998). Most, if not all, activin in plasma appears to be bound by follis- 


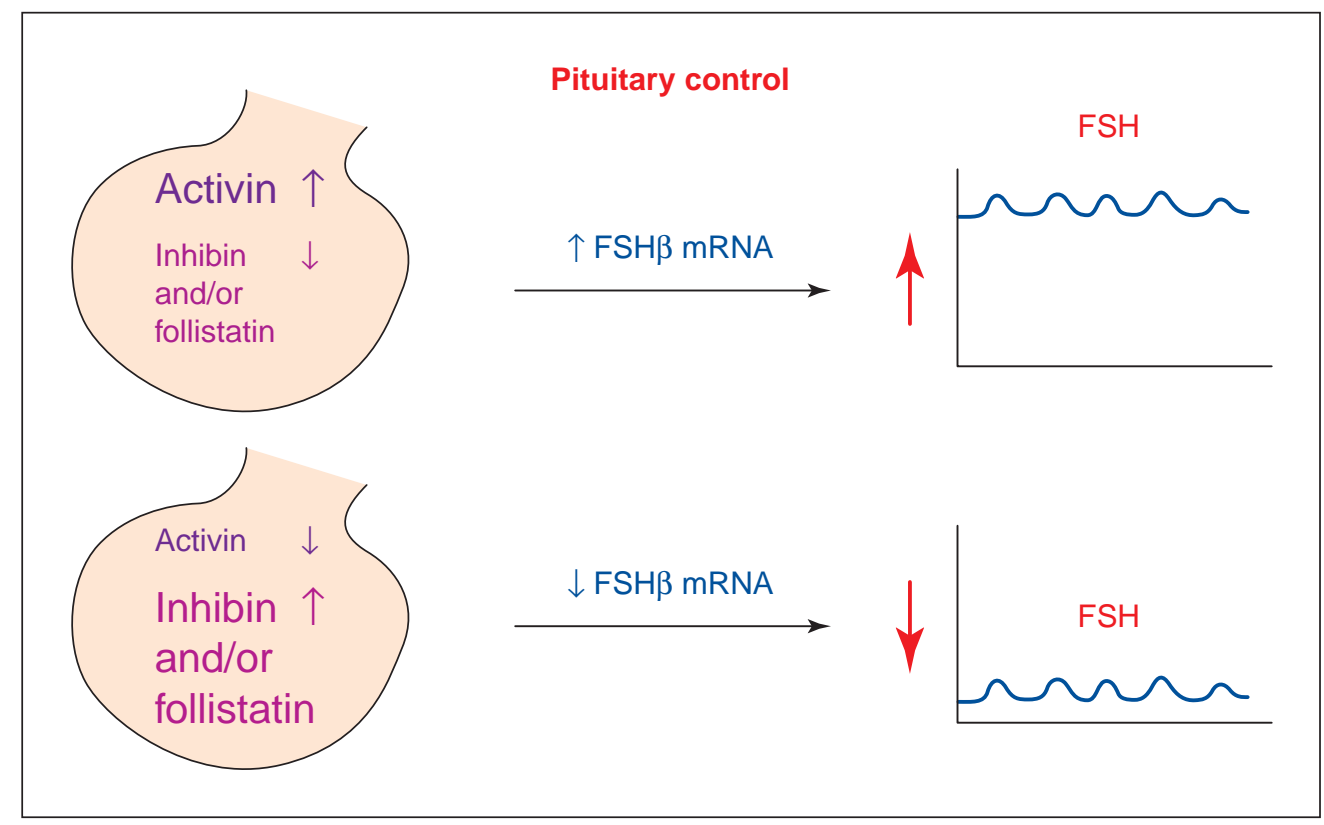

Fig. 4. Schematic representation of the local pituitary loop involving activin, inhibin and follistatin and their impact on FSH secretion. This model predicts that increases in pituitary activin or decreases in inhibin and follistatin would increase FSH secretion. In contrast, decreases in activin or increases in follistatin-inhibin would lower FSH secretion.

tatin and to be biologically inert. Therefore, the actions of activin and follistatin in regulating $\mathrm{FSH}$ release are believed to be mediated via autocrine-paracrine mechanisms at the pituitary (Fig. 4).

The functional overlap among these regulators must be taken into account to understand how they modulate FSH production and secretion (Fig. 4). Inhibins and activins are functional opposites (Ying, 1988). Although there is evidence that there are specific, separate receptors for inhibin (Draper et al., 1998; Hertan et al., 1999), inhibin is able to bind to activin receptors, albeit with lower affinity (Mathews and Vale, 1991; Martens et al., 1997), and to antagonize the action of activin (Weiss et al., 1993). Follistatin, a binding protein of activin and inhibin, neutralizes activin but not inhibin action (Robertson, 1992). Therefore, the relative proportion of these three regulators is an important consideration in determining their overall impact on FSH release. An increase in activin or a decrease in inhibin and follistatin production at the anterior pituitary would increase FSH production and secretion. Conversely, a decrease in activin or an increase in inhibin and follistatin would decrease FSH production and secretion.

\section{Regulation of pituitary factors controlling FSH synthesis and release}

The factors involved in regulating anterior pituitary activin, inhibin and follistatin to control FSH synthesis and release in different physiological situations may be both hypothalamic and endocrine. For example, there is a reciprocal relationship between the expression of FSH $\beta$ and mRNAs encoding follistatin in response to different patterns of GnRH treatments in perifused, rat pituitary cells (Kirk et al., 1994; Besecke et al., 1996). Infrequent pulses of $\mathrm{GnRH}$ stimulate only expression of $\mathrm{FSH} \beta \mathrm{mRNA}$, whereas higher frequency pulses increase expression of follistatin mRNA (Kirk et al., 1994; Besecke et al., 1996). However, it is slow frequency GnRH pulses that selectively increase circulating concentrations of FSH in vivo (Clarke et al., 1984; Wildt et al., 1981; Marshall et al., 1992). Dalkin et al. (1999) have shown that low amplitude GnRH pulses also increase expression of activin $\beta B$ mRNA. Collectively, these findings indicate that the local pituitary milieu is the means by which changes in GnRH input lead to differential release patterns of $\mathrm{LH}$ and FSH. However, the suggested role of activin, inhibin and follistatin in the local regulation of pituitary $\mathrm{FSH}$ is based on observations of changes in the steady states of their mRNAs and are yet to be validated at the protein level.

Although the changes in baseline concentration of FSH release can be explained by changes in regulatory factors produced in the anterior pituitary, it is unclear whether such changes can also explain the episodic pattern of FSH release. Regulatory factors must also undergo correlated changes to account for the non-GnRH-dependent episodic mode of FSH secretion. At the periphery, there is evidence that inhibin is secreted in a pulsatile manner (McNeilly and Baird, 1989; Lockwood et al., 1998). Can the pulsatile mode of peripheral inhibin secretion account for the non-GnRH-dependent episodic pattern of $\mathrm{FSH}$ release, and do the local pituitary 
regulatory factors fluctuate in a similar manner? What is the relative contribution of the peripheral inhibin and the local pituitary regulatory factors in modulating FSH secretion? A scenario can be envisioned in which the combined action of a number of factors (for example, inhibin, activin, follistatin and oestradiol) could lead to the appearance of FSH 'pulses' and an episodic pattern of FSH secretion (Fig. 5a).

If changes in local regulatory pituitary factors account for the non-GnRH-dependent episodic component of FSH secretion, changes in the interactions of these regulators and the consequent change in peripheral FSH must involve multiple intermediary steps (stimulus $\rightarrow$ changes in FSH regulatory proteins $\rightarrow$ FSH biosynthesis $\rightarrow$ FSH secretion). The time taken for these steps to be completed may result in the stimulus for a change in FSH release and the FSH release appearing unrelated or phase shifted in relation to the stimulus. For instance, suppressive effects of inhibin on FSH production and secretion in sheep are evident 4-6 h after inhibin administration (Wu et al., 1987) and the decrease in plasma FSH is equivalent to the half-life clearance of $\mathrm{FSH}$, indicating a shutdown of FSH release (McNeilly 1984). Although the effects on mRNA encoding FSH $\beta$ are manifested sooner, other studies in male monkeys have shown a substantial lag between the time of administration of inhibin and peripheral FSH suppression (Ramaswamy et al., 1998). This mode of regulation differs from the secretagogue $(\mathrm{GnRH})$-induced burst of $\mathrm{LH}$ and $\mathrm{FSH}$ release (stimulus secretion coupling).

Although changes in local pituitary factors may contribute to the appearance of an episodic pattern of FSH secretion, what other mechanisms can explain the non-GnRH associated pulses of FSH? What evidence is there in support of the existence of a second neural trigger ( $\mathrm{FSH}$ releasing factor; FSH-RF) (Fig. 5b) to account for the discordant pattern of episodic LH and FSH release?

\section{Evidence supporting the existence of a separate FSH-releasing factor}

Evidence for separate hypothalamic areas controlling $\mathrm{LH}$ and $\mathrm{FSH}$ secretion

Ablation (Lumpkin and McCann, 1984) and deafferentation (Lamperti and Hill, 1987) of the dorsal anterior hypothalamic area (DAHA) or electrochemical stimulation of hypothalamic regions apart from those that regulate $\mathrm{LH}$ secretion (Chappel and Barraclough, 1976) provide evidence for the existence of a specific site controlling FSH release. The strongest support for involvement of distinct neural regions for control of $\mathrm{FSH}$ pulsatility comes from studies of Lumpkin et al. (1989) demonstrating that radiofrequency lesions of the DAHA abolished FSH pulsatility without altering LH pulsatility. Selective suppression of FSH pulsatility is also observed after lesion of the caudal and mid-median eminence (Marubayashi et al., 1999). These observations could be interpreted as indicating that an FSH-RF is produced in neurones with cell bodies in the DAHA with axons projecting into the caudal and mid-median eminence.

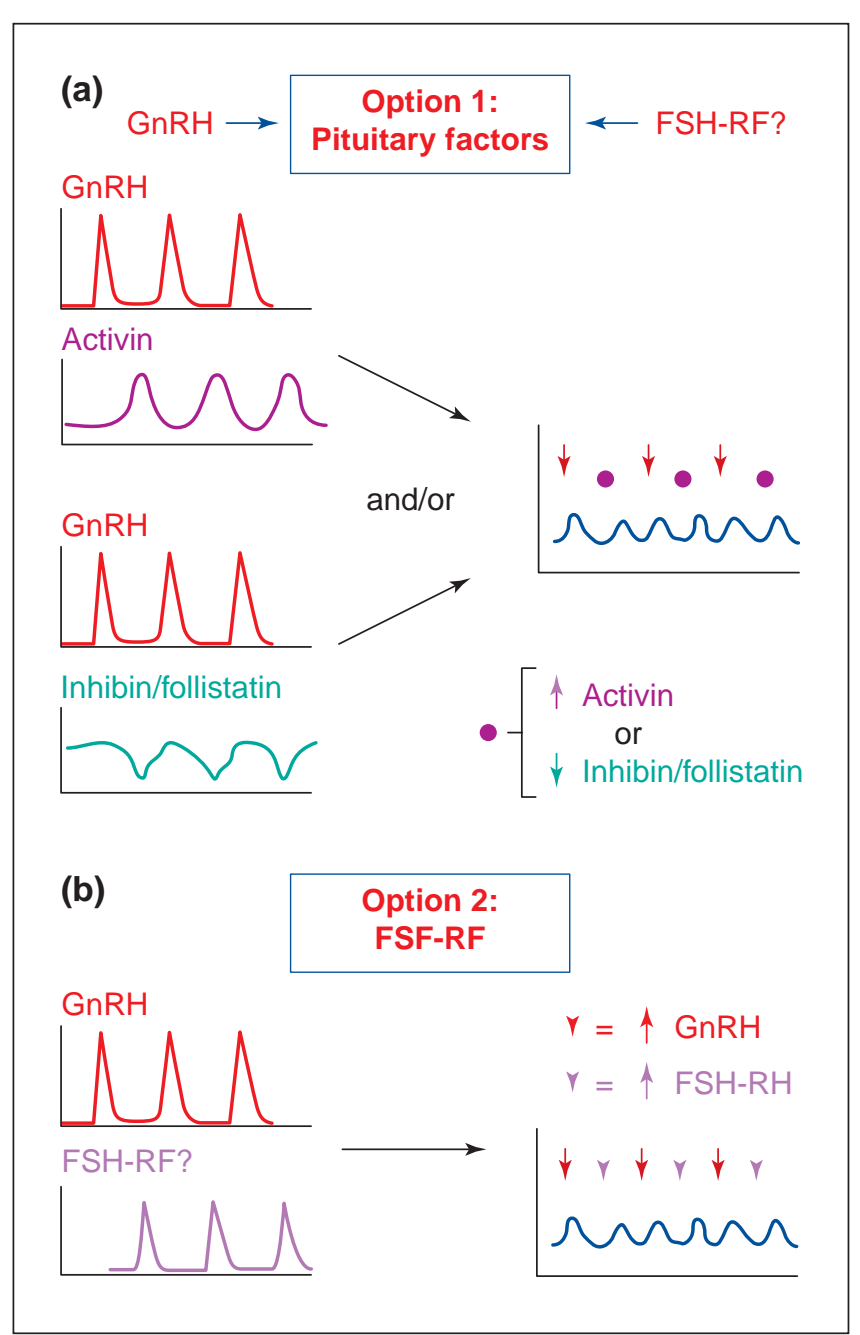

Fig. 5. Schematic representation of two mechanisms by which local pituitary factors or an FSH-releasing factor (FSH-RF) can account for the observed episodic pattern of FSH release. (a) Possible means by which changes in activin (a positive regulator of FSH) and inhibin-follistatin-oestradiol (negative regulators of FSH), in conjunction with $\mathrm{GnRH}$, can account for GnRH-associated and non-GnRH-associated pulses of FSH. Although not represented in this figure, there is likely to be a time lag between changes in local tone and the manifestation of changes in FSH. In turn, these local factors appear to be regulated by GnRH. (b) Possible means by which $\mathrm{GnRH}$, in conjunction with the putative $\mathrm{FSH}-\mathrm{RF}$, can account for GnRH-associated and non-GnRHassociated pulses of FSH.

\section{Biochemical evidence for an FSH-releasing factor}

Igarashi and McCann (1964) were the first to suggest the existence of a separate FSH-RF responsible for discordant FSH secretion. Initial separation of FSH-releasing activity from sheep hypothalami was achieved by gel filtration on a Sephadex G-25 column followed by carboxymethyl cellulose chromatography (Dhariwal et al., 1965). In these studies, FSH-releasing activity emerged just before elution of the 
classic GnRH. Differential separation methods were used by two groups to achieve clearer separation of FSH and LH-releasing activities from extracts of pig and sheep hypothalami (Fuchs et al., 1979; McCann et al., 1983). Subsequent characterizations revealed that, while the bulk of the $\mathrm{GnRH}$ activity was localized to the anterior median eminence, the FSH-releasing activity of the posterior median eminence was much greater than could be accounted for by its GnRH content (Mizunuma et al., 1983). A preparation enriched with biologically active FSH-RF free of GnRH was obtained subsequently by Lumpkin et al. (1987) after ion exchange chromatography of sheep hypothalamic extracts. Despite the recognized interest and importance of the topic and the mounting neuroanatomical, biochemical and physiological evidence supporting the existence of an FSH-RF in the hypothalamus, to date, a physiologically relevant FSH-RF has yet to be fully isolated and characterized.

\section{Is a variant of $\mathrm{GnRH}$ the putative FSH-releasing factor?}

Molecular advances in the identification of variant forms of GnRH open up the possibility that one form is the putative FSH-RF. The factor must be capable of selectively stimulating $\mathrm{FSH}$ over $\mathrm{LH}$ or at least be a more potent releaser of $\mathrm{FSH}$ than of $\mathrm{LH}$ to be categorized as an $\mathrm{FSH}$ releasing factor. Nine forms of $\mathrm{GnRH}$ have been identified in lower vertebrates (Lin et al., 1998) and a second form of $\mathrm{GnRH}$ has also been identified in higher mammals (Lescheid et al., 1997; White et al., 1998, Urbanski et al., 1999). A putative receptor for this second form of $\mathrm{GnRH}$ has been identified in humans (Millar et al., 1999). Although this second form of $\mathrm{GnRH}$ has been shown to release LH (Lescheid et al., 1997), no information is yet available regarding its ability to release $\mathrm{FSH}$.

Studies using rat hemi-pituitary cultures show that lamprey GnRH III releases FSH at much lower doses than those required for $\mathrm{LH}(\mathrm{Yu}$ et al., 1997). Testing in vivo showed a small selective increase (approximately 20\%) in $\mathrm{FSH}$ over the saline controls, indicating that the lamprey GnRH-III is a homologue of mammalian FSH-RF, although more rigorous testing is required to establish whether this is the case. Such testing should include: (1) detailed dose-response studies in vivo in which the stress effects observed, for example, in the studies of Yu et al. (1997) can be minimized: (2) immunocytochemical localization of the counterpart of lamprey GnRH-III in the mammalian brain; (3) checking that the lesioning of areas where this variant GnRH localizes leads to selective elimination of FSH pulsatility (unless localization is restricted to sites, such as DAHA, implicated in the selective control of FSH); and, more importantly (4) documenting the expression of the gene encoding the counterpart of lamprey $\mathrm{GnRH}-\mathrm{III}$ in the hypothalamus of higher vertebrates.

\section{Conclusions}

In summary, if the pivotal role FSH plays in controlling

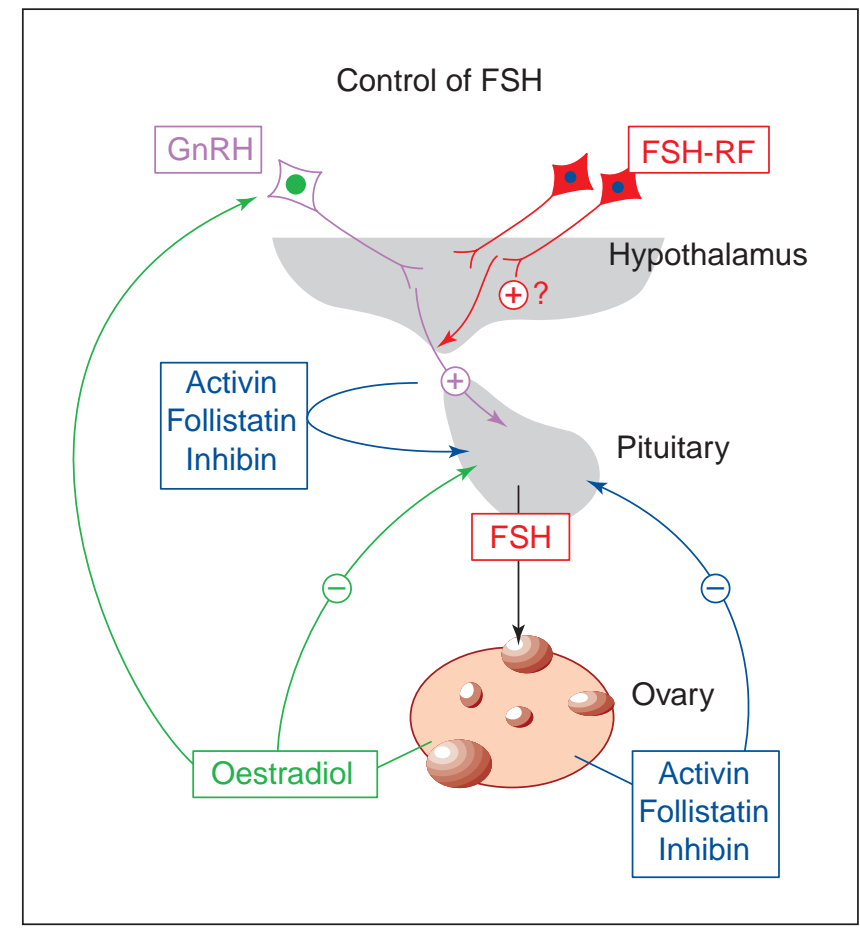

Fig. 6. Schematic summary of the neuroendocrine control of FSH, showing the hypothalamic, ovarian and pituitary hormones involved in the control of $\mathrm{FSH}$ production and secretion. At the hypothalamus, $\mathrm{GnRH}$ is a known stimulator of FSH release. There is also evidence in support of the existence of a hypothalamic FSH-releasing factor (FSH-RF). At the pituitary, a local loop involving activin, inhibin and follistatin appears to be operational. At the ovary, oestradiol and inhibin are two major negative feedback regulators of FSH. Although the ovary produces both activin and follistatin, these hormones are not believed to play an endocrine role.

follicular development is considered, multiple regulatory and perhaps redundant mechanisms appear to be in place to ensure its production and release (Fig. 6). In addition to the established role of $\mathrm{GnRH}$ in stimulating FSH secretion, several other factors have been implicated as selective regulators of FSH release. Gonadal steroids and several FSH regulatory proteins including activins, inhibins and follistatins have major $\mathrm{FSH}$ regulatory roles, with oestradiol and inhibin both providing the primary inhibitory inputs. Studies indicate that activins, inhibins and follistatins are produced not only at the gonad but also at the pituitary and, therefore, have the potential to exert local modulatory effects on FSH secretion. Although neuroanatomical, biochemical and physiological evidence to date support the existence of a separate FSH-RF, this factor has yet to be isolated and purified.

\section{References}

Key references are identified by asterisks.

Baird DT, Campbell BK, Mann GE and McNeilly AS (1991) Inhibin and oestradiol in the control of FSH secretion in the sheep Journal of Reproduction and Fertility Supplement 43 125-138

Barraclough CA and Wise PM (1982) The role of catecholamines in the 
regulation of pituitary luteinizing hormone and follicle-stimulating hormone secretion Endocrine Reviews 3 91-119

Besecke LM, Guendner MJ, Schneyer AL, Bauer-Dantoin AC, Jameson JL and Weiss J (1996) Gonadotropin-releasing hormone regulates folliclestimulating hormone-beta gene expression through an activin/follistatin autocrine or paracrine loop Endocrinology 137 3667-3673

Bishop W, Fawcett CP, Krulich L and McCann SM (1972) Acute and chronic effects of hypothalamic lesions on the release of $\mathrm{FSH}, \mathrm{LH}$ and prolactin in intact and castrated rats Endocrinology 91 643-656

Brown P and McNeilly AS (1999) Transcriptional regulation of pituitary gonadotrophin subunit genes Reviews of Reproduction 4 117-124

Chappel SC (1985) Neuroendocrine regulation of luteinizing hormone and follicle stimulating hormone: a review Life Sciences 36 97-103

Chappel SC and Barraclough CA (1976) Hypothalamic regulation of pituitary FSH secretion Endocrinology 98 927-935

Chappel S, Miller C and Hyland L (1984) Regulation of the pulsatile releases of luteinizing and follicle-stimulating hormones in ovariectomized hamsters Biology of Reproduction 30 628-636

Childs GV (1985) Shifts in gonadotrophin storage in cultured gonadotropes following GnRH stimulation in vitro. Peptides 6 103-107

Childs GV (1986) Functional ultrastructure of gonadotropes: a review. In Current Topics in Neuroendocrinology Vol. 7 49-97 Eds D Ganten and D Pfaff. Springer-Verlag, Berlin

Clarke IJ, Cummins JT and de Kretser DM (1983) Pituitary gland function after disconnection from hypothalamic influences in the sheep Neuroendocrinology 36 376-384

Clarke IJ, Cummins JT, Findlay JK, Burman KJ and Doughton BW (1984) Effects on plasma luteinizing hormone and follicle-stimulating hormone of varying the frequency and amplitude of gonadotrophin-releasing hormone pulses in ovariectomized ewes with hypothalamopituitary disconnection Neuroendocrinology 39 214-221

Clarke IJ, Rao A, Fallest PC and Shupnik MA (1993) Transcription rate of the follicle stimulating hormone ( $\mathrm{FSH}$ ) beta subunit gene is reduced by inhibin in sheep but this does not fully explain the decrease in mRNA Molecular and Cellular Endocrinology 91 211-216

Culler MD and Negro-Vilar A (1987) Pulsatile follicle-stimulating hormone secretion is independent of luteinizing hormone-releasing hormone (LHRH): pulsatile replacement of LHRH bioactivity in LHRHimmunoneutralized rats Endocrinology 120 2011-2021

Dalkin AC, Haisenleder DJ, Gilrain JT, Aylor K, Yasin M and Marshall JC (1999) Gonadotrophin-releasing hormone regulation of gonadotrophin subunit gene expression in female rats: actions on follicle-stimulating hormone beta messenger ribonucleic acid (mRNA) involve differential expression of pituitary activin (beta-B) and follistatin mRNAs Endocrinology 140 903-908

Denef C, Hautekeete E and Dewals R (1978) Monolayer cultures of gonadotrophs separated by velocity sedimentation: heterogeneity in response to luteinizing hormone-releasing hormone Endocrinology $103736-747$

DePaolo LV (1991) Hypersecretion of follicle-stimulating hormone (FSH) after ovariectomy of hypophysectomized, pituitary-grafted rats: implications for local regulatory control of FSH Endocrinology 128 1731-1740

*DePaolo LV, Bicsak TA, Erickson GF, Shimasaki S and Ling N (1991) Follistatin and activin: a potential intrinsic regulatory system within diverse tissues Proceedings of the Society for Experimental Biology and Medicine 198 500-512

Dhariwal APS, Nallar R, Batt M and McCann SM (1965) Separation of follicle-stimulating hormone-releasing factor from luteinizing hormonereleasing factor Endocrinology 76 290-294

Dobson H and Ward WR (1977) Alterations in plasma gonadotrophin patterns caused by sodium pentobarbitone in ewes at oestrus and in anoestrous ewes after infusion of oestradiol Journal of Endocrinology 75 109-118

Draper LB, Matzuk MM, Roberts VJ, Cox E, Weiss J, Mather JP and Woodruff TK (1998) Identification of an inhibin receptor in gonadal tumors from inhibin alpha-subunit knockout mice Journal of Biological Chemistry 273 398-403

Farnworth PG (1995) Gonadotropin secretion revisited. How many ways can FSH leave a gonadotroph? Journal of Endocrinology 145 387-395

Fuchs S, Lundanes E, Leban J, Folkers K and Bowers C (1979) On the existence and separation of the follicle stimulating hormone releasing hormone from the luteinizing hormone releasing hormone Biochemical and Biophysical Research Communications 88 92-96

Gharib SD, Wierman ME, Shupnik MA and Chin WW (1990) Molecular biology of the pituitary gonadotropins Endocrine Reviews 11 177-199

Gross KM, Matsumoto AM and Bremner WJ (1987) Differential control of luteinizing hormone and follicle-stimulating hormone secretion by luteinizing hormone-releasing hormone pulse frequency in man Journal of Clinical Endocrinology and Metabolism 64 675-680

Hall JE, Whitcomb RW, Rivier JE, Vale WW and Crowley WF, Jr (1990)Differential regulation of luteinizing hormone, follicle-stimulating hormone, and free alpha-subunit secretion from the gonadotrope by gonadotropin-releasing hormone $(\mathrm{GnRH})$ : evidence from the use of two $\mathrm{GnRH}$ antagonists Journal of Clinical Endocrinology and Metabolism 70 328-335

Hertan R, Farnworth PG, Fitzsimmons KL and Robertson DM (1999) Identification of high affinity binding sites for inhibin on ovine pituitary cells in culture Endocrinology 140 6-12

Igarashi M and McCann SM (1964) A hypothalamic follicle stimulating hormone releasing factor Endocrinology 74 446-452

Kalra SP (1976) Ovarian steroids differentially augment pituitary FSH release in deafferented rats Brain Research 114 541-544

Karsch FJ and Evans NP (1996) Feedback actions of estradiol on GnRH secretion during the follicular phase of the estrous cycle Acta Neurobiologiae Experimentalis 56 715-725

Kartun K and Schwartz NB (1987) Effects of a potent antagonist to gonadotropin-releasing hormone on male rats: luteinizing hormone is suppressed more than follicle-stimulating hormone Biology of Reproduction 36 103-108

Kirk SE, Dalkin AC, Yasin M, Haisenleder DJ and Marshall JC (1994) Gonadotropin-releasing hormone pulse frequency regulates expression of pituitary follistatin messenger ribonucleic acid: a mechanism for differential gonadotrope function Endocrinology 135 876-880

Lamperti A and Hill L (1987) The effects of anterior hypothalamic deafferentation on FSH-releasing activity in the intact female hamster Experimental Brain Research 68 189-194

*Lescheid DW, Terasawa E, Abler LA, Urbanski HF, Warby CM, Millar RP and Sherwood NM (1997) A second form of gonadotropin-releasing hormone $(\mathrm{GnRH})$ with characteristics of chicken $\mathrm{GnRH}-\mathrm{Il}$ is present in the primate brain Endocrinology 138 5618-5629

Lin XW, Otto CJ and Peter RE (1998) Evolution of neuroendocrine peptide systems: gonadotropin-releasing hormone and somatostatin Comparative Biochemistry and Physiology. Part C Pharmacology, Toxicology, Endocrinology 119 375-388

Lockwood GM, Muttukrishna S, Groome NP, Matthews DR and Ledger WL (1998) Mid-follicular phase pulses of inhibin B are absent in polycystic ovarian syndrome and are initiated by successful laparoscopic ovarian diathermy: a possible mechanism regulating emergence of the dominant follicle Journal of Clinical Endocrinology and Metabolism 83 1730-1735

Lumpkin MD and McCann SM (1984) Effect of destruction of the dorsal anterior hypothalamus on follicle-stimulating hormone secretion in the rat Endocrinology 115 2473-2480

Lumpkin MD, Moltz JH, Yu WH, Samson WK and McCann SM (1987) Purification of FSH-releasing factor: its dissimilarity from LHRH of mammalian, avian and piscian origin Brain Research Bulletin 18 175-178

Lumpkin MD, McDonald JK, Samson WK and McCann SM (1989) Destruction of the dorsal anterior hypothalamic region suppresses pulsatile release of follicle stimulating hormone but not luteinizing hormone Neuroendocrinology 50 229-235

*McCann SM, Mizunuma H, Samson WK and Lumpkin MD (1983) Differential hypothalamic control of FSH secretion: a review Psychoneuroendocrinology 8 299-308

McConnell DS, Wang QF, Sluss PM, Bolf N, Khoury RH, Schneyer AL, Midgley AR, Jr, Reame NE, Crowley WF, Jr and Padmanabhan V 
(1998) A two-site chemiluminescent assay for activin-free follistatin reveals that most follistatin circulating in men and normal cycling women is in an activin-bound state Journal of Clinical Endocrinology and Metabolism 83 851-858

McNeilly AS (1984) Changes in FSH and the pulsatile secretion of $\mathrm{LH}$ during the delay in oestrus induced by treatment of ewes with bovine follicular fluid Journal of Reproduction and Fertility 72 165-172

McNeilly AS (1988) The control of FSH secretion Acta Endocrinologica Supplement (Copenhagen) 288 31-40

McNeilly AS and Baird DT (1989) Episodic secretion of inhibin into the ovarian vein during the follicular phase of the oestrous cycle in the ewe Journal of Endocrinology 122 287-292

Marshall JC, Dalkin AC, Haisenleder DJ, Griffin ML and Kelch RP (1992) $\mathrm{GnRH}$ pulses - the regulators of human reproduction Transactions of the American Clinical and Climatological Association 104 31-46

Martens JW, de Winter JP, Timmerman MA, McLuskey A, van Schaik RH, Themmen AP and de Jong $\mathbf{F}$ (1997) Inhibin interferes with activin signaling at the level of the activin receptor complex in the Chinese hamster ovary cells Endocrinology 138 2928-2936

Marubayashi U, Yu WH and McCann SM (1999) Median eminence lesions reveal separate hypothalamic control of pulsatile follicle-stimulating hormone and luteinizing hormone release Proceedings of the Society for Experimental Biology and Medicine 220 139-146

Mather JP, Woodruff TK and Krummen LA (1992) Paracrine regulation of reproductive function by inhibin and activin Proceedings of the Society for Experimental Biology and Medicine 201 1-15

Mathews LS and Vale WW (1991) Expression cloning of an activin receptor, a predicted transmembrane serine kinase Cell 65 973-982

Midgley AR, Jr, McFadden K, Ghazzi M, Karsch FJ, Brown MB, Mauger DT and Padmanabhan V (1997) Nonclassical secretory dynamics of LH revealed by hypothalamo-hypophyseal portal sampling of sheep Endocrine 6 133-143

Millar R, Conklin D, Lofton-Day C, Hutchinson E, Troskie B, Illing N, Sealfon SC and Hapgood J (1999) A novel human GnRH receptor homolog gene: abundant and wide tissue distribution of the antisense transcript Journal of Endocrinology 162 117-126

Mizunuma H, Samson WK, Lumpkin MD and McCann SM (1983) Evidence for an FSH-releasing factor in the posterior portion of the rat median eminence Life Sciences 33 2003-2009

Muttukrishna S, Fowler PA, George L, Groome NP and Knight PG (1996) Changes in peripheral serum levels of total activin A during the human menstrual cycle and pregnancy Journal of Clinical Endocrinology and Metabolism 81 3328-3334

Muyan M, Ryzmkiewicz DM and Boime I (1994) Secretion of lutropin and follitropin from transfected $\mathrm{GH} 3$ cells: evidence for separate secretory pathways Molecular Endocrinology 8 1789-1797

Normolle DP, Evans NP, Dahl, GE and Padmanabhan V (1997) A novel approach to assess changes in endocrine secretion: analysis of $\mathrm{GnRH}$ antagonist (Nal-Glu) suppression of gonadotropin release in ovariectomized ewes European Journal of Endocrinology 136 519-530

*Padmanabhan V, McFadden K, Mauger DT, Karsch FJ and Midgley AR, Jr (1997) Neuroendocrine control of FSH secretion I. Direct evidence for separate episodic and basal components of FSH secretion Endocrinology 138 424-432

Pau KY, Gleissman PM, Oyama T and Spies HG (1991) Disruption of GnRH pulses by anti-GnRH serum and Phentolamine obliterates pulsatile $\mathrm{LH}$ but not FSH secretion in ovariectomized rabbits Neuroendocrinology 53 382-391

Ramaswamy S, Pohl CR, McNeilly AS, Winters SJ and Plant TM (1998) The time course of follicle-stimulating hormone suppression by recombinant human inhibin $\mathrm{A}$ in the adult male rhesus monkey (Macaca mulatta) Endocrinology 139 3409-3415

Robertson DM (1992) Follistatin/activin-binding protein Trends in Endocrinology and Metabolism 3 65-68

Savoy-Moore RT and Schwartz NB (1980) Differential control of FSH and LH secretion International Review of Physiology 22 203-248

Schally AV, Arimura A, Kastin AJ, Matsuo H, Baba Y, Redding TW,
Nair RM, Debeljuk L and White WF (1971) Gonadotropin-releasing hormone: one polypeptide regulates secretion of luteinizing and follicle-stimulating hormones Science 173 1036-1038

Schwartz NB, Rivier C, Rivier J and Vale WW (1985) Effect of gonadotropin-releasing hormone antagonists on serum folliclestimulating hormone and luteinizing hormone under conditions of singular follicle-stimulating hormone secretion Biology of Reproduction 32 391-398

Sheridan R, Loras B, Surardt L, Ectors F and Pasteels JL (1979) Autonomous secretion of follicle-stimulating hormone by long term organ cultures of rat pituitaries Endocrinology 104 198-204

Strobl FJ and Levine JE (1988) Estrogen inhibits luteinizing hormone (LH), but not follicle-stimulating hormone secretion in hypophysectomized pituitary-grafted rats receiving pulsatile LH-releasing hormone infusions Endocrinology 123 622-630

Thomas SG and Clarke IJ (1997) The positive feedback action of estrogen mobilizes LH-containing, but not FSH-containing secretory granules in ovine gonadotropes Endocrinology 138 1347-1350

Turgeon JL and Waring DW (1982) Differential changes in the rate and pattern of follicle-stimulating hormone secretion from pituitaries of cyclic rats superfused in vitro. Endocrinology 111 66-73

Ulloa-Aguirre A, Midgley AR, Jr, Beitins IZ and Padmanabhan V (1995) Follicle stimulating isohormones: biological characterization and physiological relevance Endocrine Reviews 16 765-787

Urbanski HF, White RB, Fernald RD, Kohama SG, Garyfallou VT and Densmore VS (1999) Regional expression of mRNA encoding a second form of gonadotropin-releasing hormone in the macaque brain Endocrinology 140 1945-1948

Wallace JM and McNeilly AS (1986) Changes in FSH and pulsatile secretion of $\mathrm{LH}$ during treatment of ewes with bovine follicular fluid throughout the luteal phase of the oestrous cycle Journal of Endocrinology $111317-327$

Weiss J, Duca KA and Crowley WF, Jr (1990) Gonadotropinreleasing hormone-induced stimulation and desensitization of free alpha-subunit secretion mirrors luteinizing hormone and folliclestimulating hormone in perifused rat pituitary cells Endocrinology 127 2364-2371

Weiss J, Harris PE, Halvorson LM, Crowley WF and Jameson JL (1992) Dynamic regulation of follicle-stimulating hormone- $\beta$ messenger ribonucleic acid levels by activin and gonadotropin-releasing hormone in perifused rat pituitary cells Endocrinology 131 1403-1408

Weiss J, Crowley WF, Jr, Halvorson LM and Jameson JL (1993) Perifusion of rat pituitary cells with gonadotropin-releasing hormone, activin, and inhibin reveals distinct effects on gonadotropin gene expression and secretion Endocrinology 132 2307-2311

White RB, Eisen JA, Kasten TL and Fernald RD (1998) Second gene for gonadotropin-releasing hormone in humans Proceedings National Academy of Sciences USA 95 305-309

*Wildt L, Hausler A, Marshall G, Hutchison JS, Plant TM, Belchetz PE and Knobil E (1981) Frequency and amplitude of gonadotropin-releasing hormone stimulation and gonadotropin secretion in the rhesus monkey Endocrinology 109 376-385

Wise PM, Rance N, Barr GD and Barraclough CA (1979) Further evidence that luteinizing hormone-releasing hormone also is follicle-stimulating hormone-releasing hormone Endocrinology 104 940-947

Wu FC, Irby DC, Clarke IJ, Cummins JT and de Kretser DM (1987) Effects of gonadotropin-releasing hormone pulse-frequency modulation on luteinizing hormone, follicle-stimulatig hormone and testosterone secretion in hypothalamo/pituitary-disconnected rams Biology of Reroduction 37 501-510

Ying SY (1988) Inhibins, activins and follistatins: gonadal proteins modulating the secretion of follicle-stimulating hormone Endocrine Reviews 9 267-293

Yu WH, Karanth S, Walczewska A, Sower SA and McCann SM (1997) A hypothalamic follicle-stimulating hormone-releasing decapeptide in the rat Proceedings National Academy of Sciences USA 94 9499-9503 